\title{
The Local Agricultural Community Exchange Outcomes and Lessons Learned from a Public-Private Initiative to Revitalize a Downtown Community
}

\author{
MICHELE CRANWELL SCHMIDT
}

$\mathrm{D}$ owntown revitalization is the goal of many communities, large and small. A vibrant downtown is often the backbone of civic life in a locale. That was certainly the case in Barre, Vermont, which turned to the Local Agricultural Community Exchange, or LACE, to spearhead a renovation of a vacant storefront in an economically depressed downtown as a spark to further development. The storefront was transformed into a center of micro-businesses started by local entrepreneurs, including a market and café, an artisan gallery, and a commercially licensed, shared-use kitchen. The space successfully connected local producers to consumers, provided employment and work skills training, built community cohesion, and improved the image of the downtown community. However, it would ultimately close in 2011 due to economic hardship related to the recession.

Barre City (population 9,052), first settled in the 1780 s in central Vermont, is located on a vast deposit of granite estimated to be four miles long, two miles wide, and ten miles deep. By the mid-1800s, Barre's granite mining industry was booming. Between 1880 and 1910, the city's population swelled from 2,060 to over 12,000 and was home to 68 granite quarries. However, the early twentieth century was detrimental to the granite industry; war, a decline in demand for large scale construction materials, and the Great Depression economically devastated the city. ${ }^{1}$ Despite its rich industrial past, today Barre is a community in distress with 16.3 percent of residents living in poverty, well above Vermont's rate of 11.5 percent. ${ }^{2}$ Further, 8.3 percent of residents are unemployed, compared to the statewide rate of 5.1 percent. $^{3}$

The effort to revitalize downtown Barre was led by a public-private partnership involving LACE, Central Vermont Community Action Council (CVCAC), and the private businesses that operated out of the storefront. The Nancy Nye Fellowship, through the Carsey Institute at the University of New Hampshire, supported the evaluation of the LACE project from 2007 to 2010. This research examined the impact

Michele Cranwell Schmidt is the 2008 recipient of the Nancy Nye Fellowship in Rural Community Development. that the LACE project had on community revitalization and economic development areas, including:

- Local micro business development and access to markets and sales income

- Consumer access to local products

- Employment and workplace training opportunities generated by the storefront

- Community cohesion and perception of the downtown community

LACE's community revitalization model drew from economic development theories that stressed the importance of human resource and microenterprise development, business incubation, and tourism promotion. ${ }^{4}$ The initiative also embodied concepts of the homegrown economy and sustainable food system as a retailer of local food and artisan products. ${ }^{5}$

\section{Study Design}

To gauge the impact of the revitalized storefront, we conducted focus groups and in-depth interviews with eight project staff twice a year by telephone or in person. ${ }^{6}$ In addition, we conducted voluntary telephone surveys with market vendors in 2009 and 2010. A total of 47 vendors completed the survey for a response rate of 66 percent. Ten vendors also participated in annual focus groups or in-depth interviews (or both). We also conducted in-store customer surveys over five days in 2008 and 2009. The customer survey had a response rate of 71 percent (125) in 2008 and 85 percent (132) in 2009. Nearly one-fourth of respondents from both years were Barre residents. Of those, 39 percent in 2008 and 26 percent in 2009 were considered low-income (on the basis of their income range and household size). In addition, the Center for Rural Studies at the University of Vermont conducted a statewide telephone survey in 2009 on consumer awareness and shopping patterns at LACE. A total of 615 respondents completed the survey. ${ }^{7}$

UNIVERSITY of NEW HAMPSHIRE 


\section{Supporting Micro-Business Development}

The LACE space was successful in supporting micro-business development. Serving local entrepreneurs and selfproclaimed "hobbyists," LACE supported 162 local artists by providing affordable exhibit space at the Gallery. In addition, local farmers and chefs gained access to affordable, shared resources of the LACE Community Kitchen (LCK) to test and produce food products. Most vendors were from the downtown community and neighboring towns. To support vendors' business development, two micro business counselors from CVCAC, a nonprofit community action agency that provides poverty alleviation programs and services in central Vermont, worked on site at LACE to assist in product development, pricing and marketing, scaling of production to a larger market, meeting quality and safety standards, managing finances, and accessing other community resources.

Each month, from 35 to 107 vendors sold products at the site. Of the Gallery vendors surveyed, 27 started their business by working with the CVCAC business counselor at LACE. All of these start-up businesses were still in business one year later. Nine vendors used the LCK, four of whom started their business because of access to the kitchen and working with the onsite business counselor. All nine businesses were still in operation at the end of this study.

\section{Access to Markets}

The Gallery and LCK helped vendors gain access to new and additional markets to support sales. Vendors worked with the Gallery for an average of 10.5 months (with a range of 1 to 21 months), and 70 percent of vendors sold their work at up to 10 other venues. One out of three of these vendors attributed the Gallery to helping them connect with new markets. Customers also directly commissioned vendors to create items.

Local food businesses used the LCK and cold storage space to start or expand their production capacity. The facility enabled vendors to prepare and store fresh and frozen packaged foods and process farm produce into value-added products, such as soup. With an increased production capacity, these food businesses expanded product sales to other direct, wholesale, and retail accounts, such as food carts, community supported agriculture shares, farmers' markets, restaurants, and grocery stores.

\section{Additional Income from Sales}

Sales revenue provided vendors with a source of income in addition to their regular job, unemployment benefits, or a fixed source such as Social Security or disability income. Extra income was critical to vendors, 58 percent of whom were at or below the federal poverty level. Gallery vendors retained 85 percent of product sales and paid a 15 percent commission to cover overhead costs.
Figure 1 plots Gallery sales revenue from March 2008 to September 2010. Sales totaled $\$ 65,859$, of which $\$ 55,980$ went back to the vendors. Total monthly sales averaged $\$ 2,125$, and vendors earned an average of $\$ 160$ per month. The amount of total sales revenue that vendors earned from the Gallery ranged from $\$ 4$ to $\$ 7,188$, and averaged $\$ 375$.

Figure 1. Monthly Gallery SAles ReVENUE From MARCh 2008 TO SEPTEMber 2010

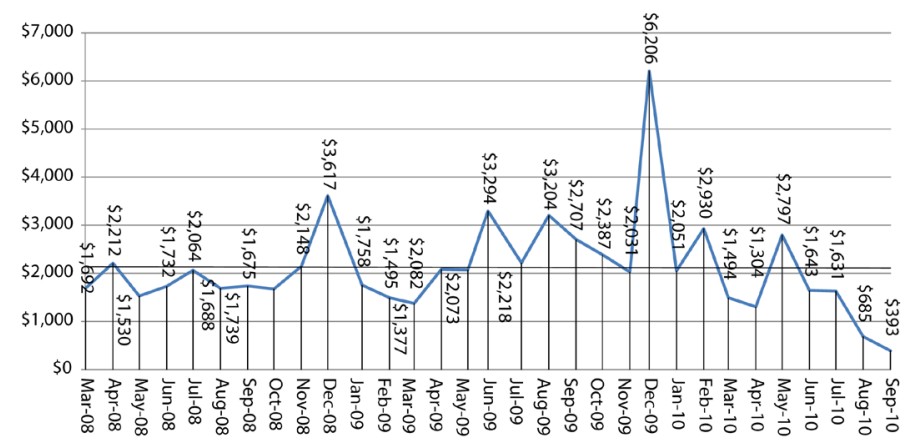

Aggregate sales data from LKC vendors were not available at the time of this report. However, two food vendors interviewed noted an increase in business revenue from using the LCK. One vendor started her business when the LCK opened because it offered her access to commercial grade equipment and was in walking distance to her home (she did not own a vehicle). She was employed solely by her food business, which provided her family with income in addition to disability benefits. A farmer who prepared vegetable soup at the LCK said that this value-added addition to his business increased the usable yield of his harvest to about 95 percent. For example, he was able to make a cream of spinach soup out of 20 pounds of spinach that had harmless, small marks on the leaves. While this raw produce would not sell in a market, the prepared soup sold for $\$ 20$ to $\$ 40$ per gallon to restaurants and grocery stores. The expansion of his business resulted in a $40-50$ percent increase in revenues, allowing him to hire one full-time and two part-time employees to support further expansion.

\section{Increasing Local Food Access}

The market, café, and Gallery at LACE sold a variety of fresh, packaged, and prepared local foods and artisan goods, providing customers with convenient access to local goods at a downtown storefront. Customer surveys showed that the number of customers who shopped frequently to occasionally at LACE increased from 33 percent of respondents in 2008 to 66 percent in 2009. In 2009, 90 percent of frequent shoppers and 53 percent of occasional shoppers were residents of the downtown community, living five miles or fewer from the storefront. In addition, 32 percent of first-time shoppers 
lived more than thirty miles away, suggesting that the store's customer base had expanded beyond the downtown area to include visitors and tourists.

The vast majority of customers liked shopping at LACE because of the store's local mission. Customers surveyed (see Figure 2) placed a high value on products that were locally produced when making purchasing decisions. Open-ended responses showed that customers shopped at the LACE market to "keep money in Vermonters' hands" and "support the local economy" They also appreciated "having a neighborhood market" where they could "support friends' businesses," as opposed to shopping only at "big-brand supermarkets."

FIGURE 2. MOST IMPORTANT QUALITY WHEN PURCHASING FOOD

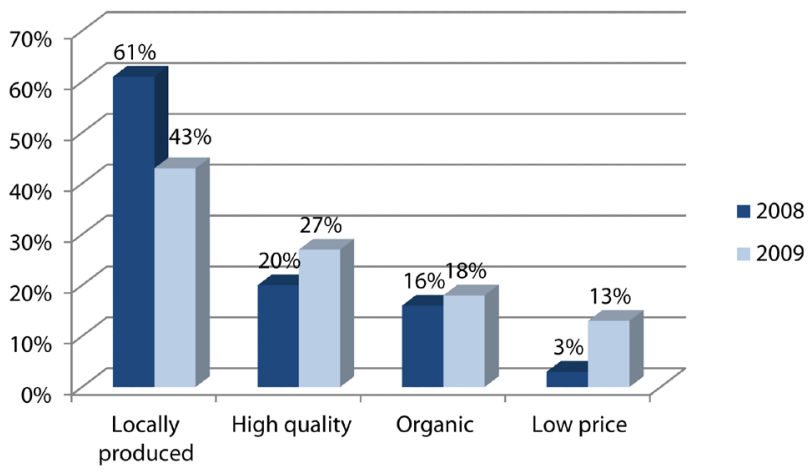

Table 1 shows that the majority of customers viewed LACE as being somewhat to very helpful in connecting consumers to local producers. However, customer ratings suggest that the storefront offerings fell short in meeting demand for reasonably priced products, possibly reflecting the increase in customers who placed a high value on low prices in 2009 (see Figure 2).

TABle 1. Customer Rating OF LOCAL PRODUCT OFFERINGS AT LACE

\begin{tabular}{l|c|ccc}
\hline & Year & $\begin{array}{c}\text { Very } \\
\text { Helpful } \\
\text { Item }\end{array}$ & $\begin{array}{c}\text { Somewhat } \\
\text { Helpful } \\
(\%)\end{array}$ & $\begin{array}{c}\text { Not } \\
\text { Helpful } \\
(\%)\end{array}$ \\
\hline $\begin{array}{l}\text { Providing a place for farmers } \\
\text { to sell products }\end{array}$ & 2008 & 89 & 11 & 0 \\
\hline Providing a place for artists & 2009 & 81 & 19 & 0 \\
and crafters to sell products & 2009 & 78 & 22 & 0 \\
\hline Providing a grocery store in & 2008 & 71 & 27 & 2 \\
the downtown area & 2009 & 68 & 29 & 3 \\
\hline Providing residents with & 2008 & 92 & 8 & 1 \\
locally produced products & 2009 & 82 & 17 & 1 \\
\hline Providing residents with & 2008 & 44 & 48 & 8 \\
reasonably priced products & 2009 & 36 & 52 & 12 \\
\hline
\end{tabular}

\section{Providing Employment and Work- place Training Opportunities}

The nonprofit and business enterprises of LACE supported job creation, employment placement, and workplace training in this economically depressed community. The area unemployment rate was 8.3 percent in 2009. After two years of operation, LACE created and supported 61.5 full-time equivalent (FTE) positions, of which 57 percent were held by low-income individuals. Positions included staff of the nonprofit, Gallery, market, and café, and jobs created by vendors (including business owners and employees). Of this total, 31 FTE were new positions and 30.5 FTE were retained positions.

The storefront was a popular work placement site for clients of social welfare and workforce training programs to gain job skills and experience. Recipients of Temporary Assistance for Needy Families (TANF) could fulfill their 5-20 hour weekly work training requirement at LACE as a way to earn their monetary award. Trainees from the Vermont Associates for Training and Development also took part in a six-month job retraining program for older adults. The supervisor of these programs observed that trainees who maximized this experience built references and improved their work ethic, professionalism, and self-confidence. After training completion, two TANF recipients were hired as part-time kitchen staff for the café. In addition, a Gallery trainee obtained employment outside of LACE in a full-time position that paid $\$ 15$ per hour. These individuals were then no longer reliant of the TANF program.

\section{Building Community Cohesion}

A sense of community spirit at LACE was evident in the customer surveys and contributed to their satisfaction with and dedication to the store. In nearly one-fourth of customer comments (22 percent), the social and family-friendly atmosphere of the store was the most enjoyable aspect of shopping at LACE. These attributes helped foster community interactions focused around food and family. Table 2 shows that the majority of customers rated LACE as somewhat to very helpful in supporting community cohesion by providing a family-friendly environment, a place to hang out, access to a café, and events for adults, children, and families.

The café and seating area provided a multi-purpose community space and focal point for patrons to eat, socialize, work, relax, and participate in LACE education programs. The café and seating area were the most commonly visited locations; 55 percent of customers surveyed in 2008 and 52 percent in 2009 used these areas. Patrons enjoyed dining at the café, with customers favoring breakfast items, daily soups, salads, and desserts. The adjacent children's play area was also an attraction for many customers and was on target with LACE's family-friendly mission. 
TABle 2. CUSTOMER RATINGS OF COMMUNITY COHESION AT LACE

\begin{tabular}{l|c|ccc}
\hline & Year & $\begin{array}{c}\text { Very } \\
\text { Helpful } \\
(\%)\end{array}$ & $\begin{array}{c}\text { Somewhat } \\
\text { Helpful } \\
(\%)\end{array}$ & $\begin{array}{c}\text { Not } \\
\text { Helpful } \\
(\%)\end{array}$ \\
\hline $\begin{array}{l}\text { Providing family-friendly } \\
\text { environment }\end{array}$ & 2008 & 94 & 6 & 0 \\
\hline \multirow{2}{*}{ Providing a place to hang out } & 2009 & 82 & 17 & 2 \\
\hline \multirow{2}{*}{ Providing residents with a café } & 2008 & 88 & 12 & 0 \\
& 2009 & 78 & 20 & 3 \\
\hline Providing events for adults, & 2009 & 71 & 29 & 0 \\
children, and families & 2008 & 71 & 28 & 4 \\
\hline
\end{tabular}

The nonprofit side of LACE used the storefront to host free or low-cost workshops, discussion groups, music events, lectures, and youth programs. LACE hosted community meals, including Friday evening dinners that incorporated guest chefs and diverse cuisine, and Sunday afternoon brunches that featured live music from area musicians. The Gallery hosted holiday and other craft fairs, which included artist demonstrations. Education programs held in the community kitchen reached a variety of audiences, targeting youth, families, and adults in low-income communities. Workshops and cooking demonstrations with groups, such as schools and senior housing programs, aimed to give participants hands-on cooking skills using local ingredients.

\section{Improving the Image of the Downtown Community}

During a focus group, Gallery vendors commented that LACE made living in Barre more "palatable," and results from customer surveys and a statewide telephone poll show that local and visiting shoppers agree. Five of the six vendors interviewed moved to Barre because of the affordability of homes in the area over their affinity for the community or downtown area. All expressed concerns for their personal safety when walking in certain parts of the downtown area, including Main Street where the storefront was located. They felt that this concern deterred visitors from the area. However, LACE and the Barre Partnership, a nonprofit of business and civic leaders dedicated to downtown revitalization, worked hard to improve the downtown image. Improved storefront shopping generated more foot traffic of working professionals and community members to visit the downtown area.
Results from the statewide opinion survey conducted in 2009 showed that 16.4 percent (98) of Vermonters polled had heard of LACE, and 41 percent (40) of those respondents had been to LACE. Of respondents who had heard of or visited LACE, 74 percent (52) felt that LACE attracted more people to shop in the downtown Barre area, and 91 percent (74) thought that LACE improved the overall image of downtown. Responses from customer surveys were consistent with statewide findings. Almost all customers surveyed rated LACE as very to somewhat helpful in improving the image of and attracting more shoppers to the downtown area (see Table 3). Furthermore, 100 percent of Barre residents surveyed felt that LACE was very helpful in improving the downtown area's tarnished image. Marketing and promotional efforts at LACE attracted local and visiting shoppers from within and outside the downtown area. The executive director of LACE believed that the opening of LACE, including a visit by Vermont's Senator Patrick Leahy, attracted new people to the area by giving them a reason to visit and shop in downtown Barre.

TABLE 3. CUSTOMER RATING OF LACE'S IMPACT ON THE DOWNTOWN COMMUNITY

\begin{tabular}{l|c|ccc}
\hline Item & Year & $\begin{array}{c}\text { Very } \\
\text { Helpful } \\
(\%)\end{array}$ & $\begin{array}{c}\text { Somewhat } \\
\text { Helpful } \\
(\%)\end{array}$ & $\begin{array}{c}\text { Not } \\
\text { Helpful } \\
(\%)\end{array}$ \\
\hline $\begin{array}{l}\text { Improving the overall image of } \\
\text { downtown Barre }\end{array}$ & 2008 & 84 & 15 & 1 \\
\hline Attracting more people to shop in & 2009 & 78 & 23 & 0 \\
the downtown Barre area & 2009 & 75 & 24 & 1 \\
\hline
\end{tabular}

\section{Challenges of the Project and a Look into the Future}

After three years of LACE's operations, staff and vendors were interviewed to discuss the challenges faced by the LACE project and projections for the future. The LACE project was successful in reaching project goals of supporting local entrepreneurs, connecting local producers to consumers, providing employment and work skills training, building community cohesion, and improving the image of the downtown community. However, as the original funding source dried up, the nonprofit and business aspects of LACE struggled to overcome inherent challenges and sustain operations. 


\section{Challenges of the Partnership}

The LACE private-public partnership faced communication breakdowns, and relationship and supervision challenges. Several staff roles were overextended, especially during the project's start-up phase. In hindsight, staff believed that money was not adequately allocated to cover staffing needs to start and manage the businesses within LACE, in addition to fulfilling grant goals. Staff also worked through interpersonal conflicts stemming from different personalities and opinions concerning project and business operations. All project staff acknowledged that "personalities and egos" sometimes got in the way of decision making and that working relationships were also strained by a series of miscommunications and misunderstandings. Interpersonal issues were also attributed to a lack of clarity around onsite supervision and the authoritative boundaries of project leaders.

\section{Challenges of Operations}

Vendors and project staff also identified challenges to carrying out project operations. Because for-profit and nonprofit entities cooperated under the larger initiative, revenue and cash flow shortfalls in one area affected the economic sustainability of the entire operation. The businesses often struggled to break even in the wake of the economic recession that weakened an already distressed, working-class community. Vendors also believed that their market base at LACE was limited due to perceived safety issues in the downtown area, because area residents are primarily low-income or on a fixed income and lacked discretionary spending, and because the larger community did not readily welcome LACE's specialty market offerings. Even though LACE was faced with initial distrust and suspicion among parts of the local community, staff perceived a shift in this opinion over time and customer surveys showed a high regard for LACE overall.

\section{Recommendations for Future Activities}

Staff and vendors provided recommendations to improve the project.

- Strengthening the partnership - Staff believed that future partnerships should set clear guidelines for how the partnership operates, including expectations of staff roles and job descriptions, and management and supervision systems. Partnerships should also determine a set schedule for how often and by what means project leaders and staff communicate. These processes and systems should be in place up front, mutually agreed upon, and periodically revisited and amended.
- Increase marketing and advertising-Suggestions included placing brochures in tourist information and Bed and Breakfast venues; mailing fliers to the local community that feature coupons and specials; showcasing vendor profiles in local newspapers; and having vendors hold demonstrations or workshops for the public.

- Training and services for vendors-Vendors recommended having more formal and informal gatherings for group-based learning to foster a strong support network among vendors and local entrepreneurs, and provide opportunities for showcasing work, sharing ideas, and receiving feedback.

- Adequate staffing-Project staff believed that all aspects of the project needed adequate staffing plans for working with vendors, managing operations, and accurately tracking sales and inventory (or space usage). Gallery staff specifically noted that the Gallery would be better sustained as an autonomous business within a shared rental space so that it could set its own hours of operation and better address safety and security issues that occur with the sale of artisan, craft, and jewelry items.

- Improvements to the market and café-Customers recommended that the businesses of LACE take measures to improve customer satisfaction, including reducing checkout time and expanding hours of operation. Customers also suggested that the market improve the product/brand selection and price of grocery items to include household and staple items, such as paper products, diapers, pet food, and generic brand options.

- Improvements to the LACE Community KitchenLCK staff recommended that facility rental rates should more accurately reflect market rates for renting a shared kitchen space and the facility be more adequately equipped to suit the needs of food processors. Staff and vendors also recommended improving the process for scheduling, tracking, and billing facility rental hours.

Author's Note: After four years of operation, the market, café, and Gallery at LACE closed due to economic hardship. The nonprofit of LACE continues to operate out of the farmers' market in downtown Barre and provides education and outreach programs at other shared community kitchen and meeting spaces. Visit the LACE blog at http://lacevt.wordpress.com/ for more information. 


\section{EN D N O T ES}

1. City of Barre, Municipal Plan (2010); U.S. Census Bureau, Census of Population \& Housing (2010).

2. U.S. Census Bureau, Small Area Income \& Poverty Estimates for states and counties (2009).

3. Vermont Department of Labor, Labor Market Information, Local Area Unemployment Statistics (2011).

4. E. J. Blakely and T. K. Bradshaw, Planning Local Economic Development, Theory and Practice (Thousand Oaks, CA: Sage, 2002); E. Edgcomb and J. Klein, Opening Opportunities, Building Ownership: Fulfilling the Promise of Microenterprise in the United States (Washington, DC: Aspen Institute, 2005); D. Faulk, "The Process and Practice of Downtown Revitalization," Review of Policy Research, vol. 23, no. 2 (2006); S. Mitchell, 10 Reasons Why Vermont's Homegrown Economy Matters and 50 Proven Ways to Revive It (Burlington, VT: Preservation Trust of Vermont, 2003).

5. G. W. Feenstra, "Local Food Systems and Sustainable Communities," American Journal of Alternative Agriculture, vol. 12 (1997): 28-36; H. Laurison and N. Young, "Oakland Food Retail Impact Study," Development Report no. 20 (Oakland, CA: Institute for Food and Development Policy, 2009); B. McKibben, Deep Economy: The Wealth of Communities and the Durable Future (New York: Holt, 2007); M.H. Shuman, Going Local: Creating Self-Reliant Communities in a Global Age (New York: Routledge, 2000).

6. The study protocol was approved by the University of Vermont's Committee on Human Research in the Behavioral Sciences. The study design was grounded in the research methods of Weiss (1998) and Patton (2002), as well as related research. See M. Cranwell and J. Kolodinsky, The Vermont Kitchens Project: Evaluation Report 2000-2003 (Burlington: Center for Rural Studies, University of Vermont, 2003); M. Cranwell and J. Kolodinsky, Micro Business Development Program of Vermont Client Outcome Report (Burlington: Center for Rural Studies, University of Vermont, 2003); J. Klein, I. Alisultanov, and A. Blair, Microenterprise as a Welfare to Work Strategy: Two-Year Findings (Washington, DC: Aspen Institute, 2003); M.C. Schmidt and J.M. Kolodinsky, "Microenterprise Development Program Success: A Path Analysis of Factors That Lead to and Mediate Client Success," Journal of Developmental Entrepreneurship, vol. 12, no. 1 (2006): 47-69; M.C. Schmidt et al., "The Impact of Microenterprise Development Training on Low-Income Clients," Journal of Extension, vol. 44, no. 2 (2006).

7. The margin of error was $+/-4$ percent with a confidence interval of 95 percent. Quantitative data were analyzed using the Statistical Package for the Social Sciences (SPSS) 18.0.
Qualitative data were analyzed using a thematic approach that assessed common and divergent themes observed in the data. See C. Glesne, Becoming Qualitative Researchers: An Introduction, $2 d$ ed. (New York: Addison Wesley Longman, 2009); M. Patton, Qualitative Research and Evaluation Methods (Thousand Oaks, CA: Sage, 2002). Research validity was verified through investigator triangulation and multiple independent reviews of data and analyses, as well as informant feedback on findings.

\section{A C K N O W LE D G M EN T S}

The author thanks Barbara Ray at Hired Pen and Curt Grimm, Laurel Lloyd, Bruce Mallory, and Amy Sterndale at the Carsey Institute for their helpful comments and suggestions.

\section{A B OUT THE AUTHOR}

Michele Cranwell Schmidt is the 2008 recipient of the Nancy Nye Fellowship in Rural Community Development and an evaluation coordinator and research specialist for rural studies at the University of Vermont.

\section{ANIV of NEWSITY HAMPSHIRE}

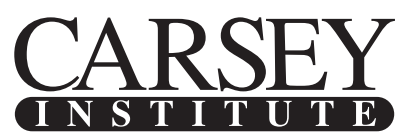

Building knowledge for families and communities

The Carsey Institute conducts policy research on vulnerable children, youth, and families and on sustainable community development. We give policy makers and practitioners timely, independent resources to effect change in their communities.

This work was supported by the Local Initiatives Support Corporation's Nancy Nye Fellowship.

Huddleston Hall

73 Main Street

Durham, NH 03824

$(603) 862-2821$

www.carseyinstitute.unh.edu 